\title{
REGULATING THE ROLE OF EXTENDED FAMILIES IN PROVIDING FINANCIAL SUPPORT UNDER MALAYSIAN LAW
}

\author{
Najibah Mohd Zin*
}

\begin{abstract}
This paper examines the adequacy of legal provisions governing the role of extended families in providing financial support under Malaysian law. This is to promote the importance of such function despite the breaking up of extended family relationships due to modernisation and urbanization. The study focuses on the Malay Muslim family where personal law is based on Shari'ah and the role of extended family is an important component of the system. Besides, other forms of financial provisions are analysed to reflect the extent of familial relationship in response to the current needs.
\end{abstract}

\section{INTRODUCTION}

In a system where the family is the nucleus of the society, the role of family members in providing emotional as well as financial support

Associate Professor, Ahmad Ibrahim Kulliyyah of Laws, International Islamic University Malaysia. This article is an improved version of a working paper presented at the Centre for Research and Family Relationship, University of Edinburgh, 27-29 $9^{\text {th }}$ June 2007. 
is undeniably material for sustainable development of family relationships. It has long been regulated under the Malaysian legislation particularly in Muslim marriages that the family members, inclusive of parents and close relatives, hold equal responsibility to maintain their dependents and it is enforceable in case of neglect. Such provision is practical in a society where an individual member is willing to take that responsibility. However, when the family relationship is no longer strong, there is no guarantee that the other family members will equally hold the responsibility in the absence of a court order.

This study is undertaken to examine relevant policies and legal provisions involving extended family in providing financial support and to look for acceptable practices in ensuring that the family well being is not adversely affected especially in cases of divorce or death of the main financial provider. Existing legislation governing financial support and decided cases for both Muslims and non-Muslims in Malaysia will be the basis for this study supported by current practices in the banking industry and financial institutions in promoting and emphasizing a structured distribution of property to close family members.

\section{FAMILY STRUCTURE IN MALAYSIA}

Traditionally, the Malaysian family is a form of extended family where both the elderly and minors will be taken care of by the other family members of close as well as distant relatives. According to a study, extended families are still the main type of household system where Malaysian families take care of their elderly relatives even in cases where they do not live under the same roof. ${ }^{1}$ In such a society, family provides love, affection, respect and security for the elderly while the monetary or financial support comes from children and grandchildren ${ }^{2}$ even though the law does not explicitly regulate such practice. In contrast, monetary

\footnotetext{
$1 \quad$ Mashitah Mohd. Yatim, "Social and Financial Support of the Aged; A Socio-economic Study on the Consequences of Ageing of Population in Three States in Peninsular Malaysia,” Journal of Family Studies, vol. 1989, 53.

2 Ibid., p. 60.
} 
contribution for the interests of minor children is well established in statutory form. ${ }^{3}$

Besides, the above study also suggests that the modernizing world and rapid social change as result of urbanization, industrialization, migration and increased female labour force participation are a threat to the current trend. The survey indicates that the family size in Malaysia is getting smaller and structurally becoming more independent from extended family ties. Homes are designed for nucleus type families, individualistic values slowly takes over the traditional values and there is a breakup of the extended family system. ${ }^{4}$ Most Malaysian modern families opt for a single simple family that normally comprises the husband, wife and children and extended family is needed normally during religious festivals and other celebrations. In another study, it further proves that the nuclear family structure is more predominant in rural areas rather than in urban areas when young rural people migrate to urban areas and set up new families away from their parental homes. ${ }^{5}$ The above observation indicates the correlation between modernization and social change that takes its form when the liability to support is a mere social obligation rather than legal. ${ }^{6}$ This situation also provides a challenge to the legal system to provide and improve legislation in coping with the needs of the society.

3 See for example Islamic Family (Federal Territories) Act 1984, ss.72-78 which is applicable for Muslims. For non-Muslims, see the Law Reform (Marriage and Divorce) Act 1976, ss. 92-99 and Married Women and Children (Maintenance) Act 1950 that provides for detailed procedures governing the claim for maintenance.

$4 \quad$ Mashitah Mohd. Yatim, "Social and Financial Support of the Aged; A Socio-economic Study on the Consequences of Ageing of Population in Three States in Peninsular Malaysia,” p. 58.

5 Jamilah Arifin, "The Changing Malaysian Family: Tracing Its Changes Through Trend Data and Research Findings," in Jamilah Ariffin and Adeline Louis (Ed) (2001) Family Wellbeing: Learning from the Past for the Betterment of the Future, Proceedings of the APFAM International Conference 2-5 November 1999, Kuala Lumpur, Johor, p. 21.

In non-Muslim families, obligation to support is mainly cultural and it is not reflected in any legislation to govern such practice. 


\section{MALAY MUSLIM FAMILIES AND THE ROLE OF EXTENDED FAMILY}

Despite the above observation on the family structure, it can reasonable be conclude that the extended family is still a common feature in the Malaysian Muslim family, which is originally Malays, and Islam had transformed the culture of the Malays long before the colonization. ${ }^{7}$ The influence of Islam on the Malays is reflected in the Federal Constitution of Malaysia 1957 that defines a Malay to be a Muslim and speaks the Malay language. ${ }^{8}$ In a Malay Muslim family, an association with a large membership of the extended family that is related by marriage and blood is very significant and eventually provides emotional as well as financial support. Furthermore, lineage is something of great importance as it reflects the honour and status of a family and must be protected. ${ }^{9}$ The role of the other family members is equally important as the religion and culture assume strong commitments from family members on any occasion. It is expected that the elder generation rears and nurtures the younger ones, and transmits to them their cultural heritage. Thus, the family makes a fundamental contribution through reproductive function and the perpetuation of its culture. ${ }^{10}$

As observed earlier, modernization and urbanization have a great impact on the structure of the Malay Muslim family where the younger generation eventually migrate to greener pastures to make a living. This change substantially affects the culture as well as the legal obligation to provide financial support especially in areas where such responsibility is

See Mohd.Talib Othman, "Islamization of the Malays: A Transformation of Culture," in Ahmad Ibrahim, Sharon Siddique, Yasmin Hussain (editors), Readings on Islam in Southeast Asia, Institute of Southeast Asia Studies, 1985, pp. 44-47 at p. 47.

$8 \quad$ The Federal Constitution 1957, Article 160.

9 Lineage is one of the five elements that need to be protected alongside with life, religion, blood, and property and those five elements constitute important components in the development of Shariah law.

10 Ahmad Abdul-Rauf, (1995) The Islamic View of Women and the Family, $3^{\text {rd }}$ Edition, USA: al Saadawi Publications, p. 60, 61. See also Hammudah Abd al Ati, (1997) The Family Structure in Islam, USA: American Trust Publication, pp. 30-32, affirms that the traditional Muslim Family structure is closer to the extended than to the nuclear type of family. 
not well regulated. A common example is the responsibility of children to support elderly parents where there is no such regulation available in statutory form for the purpose of enforcement though such liability is well established in Sharī'ah law. ${ }^{11}$

\section{THE INFLUENCE OF SHARI' 'AH LAW IN REGULATING THE ROLE OF EXTENDED FAMILY}

The role of the father and paternal relation as guardian in the absence of father is an important stage to invoke financial responsibility borne by family members towards minors or the disabled. The basis for such ruling is based on the Qur'ānic verse that states;

"Mother shall give suck to their offspring for two whole years, if the father wishes to complete the term. But he shall bear the costs of their food and clothing on equitable terms." 12

There is no doubt that the father is the sole financial provider in a nucleus family and the father will take portion of inheritance property after the death of the son or daughter. ${ }^{13}$ However, in the absence of the father, other members in the family eventually will take that responsibility to provide financial needs. Male family members assume this responsibility as explicitly emphasized in Islamic injunctions. Therefore, the paternal grandfather takes the lead followed by the rest of family members from the male paternal relations as the Sharī'ah law allotted for them some shares in inheritance property. The Qur'ān states:

"From what is left by parents and those nearest related there is a share for men and a share for women, whether the property be small or large, a determinate share." ${ }^{14}$

11 The general rule is based on several Qur'ānic verses and tradition of the Prophet that requires the children to treat their parents fairly. See the Qur'ān, 17:23 and 24; 46:15.

12 The Qur'ān, 2: 233.

13 Both father and mother are entitled to inheritance property.

14 The Qur'ān, 4:7. 
Reinforcement through legal mechanisms of inheritance is to promote a sense of responsibility and mutual concern. Those who are decreed with such responsibility are legally and permanently forbidden from marrying, the father, father in law, son in law, brother, her brother, paternal and maternal uncle and nephews. ${ }^{15}$ Allotment of responsibility through inheritance is explained in the Qur'ān that reads;

"Allah (thus) directs you as regards your Children's (Inheritance): to the male, a portion equal to that of two females: if only daughters, two or more, their share is two-thirds of the inheritance; if only one, Her share is a half. For parents, a sixth share of the inheritance to each, if the deceased left children; if no children, and the parents are the (only) heirs, the mother has a third; if the deceased left brothers (or sisters) the mother has a sixth (the distribution in all cases ('s) after the payment of legacies and debts. Ye know not whether your parents or your Children are nearest to you in benefit. these are settled portions ordained by Allah. And Allah is All-knowing, All-wise."

"In what your wives leave, your share is a half, if They leave no child; but if They leave a child, ye get a fourth; after payment of legacies and debts. In what ye leave, their share is a fourth, if ye leave no child; but if ye leave a child, They get an eighth; after payment of legacies and debts. if the man or woman whose inheritance is In question, has left neither ascendants nor descendants, but has left a brother or a sister, Each one of the two gets a sixth; but if more than two, They share In a third; after payment of legacies and debts; so that no loss is caused (to any one). Thus is it ordained by Allah. and Allah is All-knowing, Most Forbearing." 16

The above quoted verses, which is fundamental to the legal provisions governing inheritance, illustrates that the male portion, which is double of the female is to be used for his own expenses and those

15 For example, see Islamic Family Law (Federal Territories) Act 1984, s. 9.

16 The Qur'ān, 4:11-12. 
under his dependants including wife, children, and parents. In some cases, his liability extends to his own brothers and sisters who are in need of financial support. Such responsibility is not imposed on women and they are free to disburse the portion as they wish. Therefore, those who are entitled to inheritance property, as suggested in the above verse, include the extended family such as brothers, uncles and cousins, besides fulfilling his own liability to support his wife and children. This entitlement to inheritance property incorporates a legal responsibility to support financially the needs of minor children of the deceased if they encounter financial difficulties.

\section{LEGISLATION ON LIABILITY TO PROVIDE FINANCIAL SUPPORT}

The duty to provide financial support is generally addressed in the Malaysian legislation for both Muslims and non-Muslims where the details of the provisions will depend on the source of the legislation itself. Sharī'ah law in Malaysia is only applicable to Muslims while the nonMuslims are governed by a separate, secular law, which is federally based. Legal proceedings involving family disputes for Muslims are governed by the Sharī'ah courts while the non Muslims are governed by the civil courts.

As far as children are concerned, the law for non-Muslims provides that it shall be the duty of a parent to maintain and contribute to the maintenance of his or her children, whether they are in his or her custody or the custody of any other person. ${ }^{17}$ Maintenance here covers basic needs such as food, clothing, accommodation and education. However, a woman or the mother of the child shall be held responsible to pay if there is a need to do so, for example when both parents are earning. ${ }^{18}$ The right to be maintained is restricted to child until he attains the age of 18 years except when the children are mentally or physically

17 See for example, The Law Reform (Marriage and Divorce) Act 1976, s. 92.

18 The Law Reform (Marriage and Divorce) Act 1976, s. 93(2). See also the decision of the court in Leow Kooi Wah $v \mathrm{Ng}$ Kok Seng Philip [1995] 1 MLJ 582. 
disabled. ${ }^{19}$ The court is not prepared to extend the scope of maintenance above 18 years though the child is about to attend tertiary education ${ }^{20}$ except when there is an agreement to extend that commitment. ${ }^{21}$ The law is applicable for both legitimate and illegitimate children. ${ }^{22}$

For Muslims, the current law i.e the Islamic Family Law Act/ Enactments/Ordinances provides for a man to maintain his children whether they are under his custody or the custody of any other person. Maintenance covers accommodation, clothing, food, medical attention and education having regards to his means or by paying the cost. ${ }^{23}$ The liability to pay continues until the child reaches the age of 18 and is extendable upon the application by the child or any other person to pursue further or higher education or training. For female, the liability to maintain is until she gets married. ${ }^{24}$

In furtherance of the above provision, the Muslim law extends its application to a person other than the father to provide financial support. The provision states:

"Except as aforesaid, it shall be the duty of a person liable under Hukum Syara', to maintain and contribute to the maintenance of children if their father is dead or his where about is unknown or if and so far as he is unable to maintain them." 25

The above provision authorizes the court to order 'a person liable under the Hukum Syara' ${ }^{26}$ to pay where the root of the principle refers

19 See for example, The Law Reform (Marriage and Divorce) Act 1976, s. 95.

20 See decision of the Federal Court in Karunairajah Rasiah $v$ Punithambigai Poniah [2004] 2 CLJ 365.

$21 \quad$ See Chin Seng Woah v Lim Shook Lin [1997] 1 CLJ 375 where the father agreed to maintain his daughters until they received their first degree.

$22 \quad$ Married Women and Children (Maintenance) Act 1950 Act 263.

23 For example, see Islamic Family Law (Federal Territories) Act 1984, s. 72.

$24 \quad$ Islamic Family Law (Federal Territories) Act 1984, s. 79.

25 Islamic Family Law (Federal Territories) Act 1984, s. 72(2).

$26 \quad$ Hukum Syara' means the law recognized by the four major schools of law i.e., Shāfi 'î̀, Hạnafīi, Mālikī and Ḥanbalī. See Islamic Family (Federal Territories) Act 1984, s. 2. 
to those who are entitled to inheritance property depending on his status in the family. It clearly addresses the function of extended family members to provide financial support in the absence of the father and to serve as a useful weapon to claim monetary contribution in cases of neglect. However, through personal observation, this provision has not been fully utilized due to lack of knowledge of the availability of such legal provision and the difficulty of getting cooperation from close relatives though a valid order has been granted. ${ }^{27}$ It may make things worse when the Sharī'ah Court is unable to enforce the order due to non-cooperation from the respective party (judgment debtor) who may disappear after the divorce. Therefore, there is a need to strengthen the enforcement mechanism in making such a provision an effective remedy for children to get their maintenance.

As for illegitimate children, the duty to maintain is on the mother or maternal relations if she is incapable of discharging the duty. ${ }^{28}$ In such a case, the child is considered as under the prerogative right of the mother to the extent that the 'father' is denied his right to claim paternity of the child. This is because the paternity of the child is established by marriage and blood relationship. ${ }^{29}$ There was a proposal to impose the liability on the 'father' to equally share the burden through a court order though such an idea was not well received by many Muslims as it is contrary to the general principle of Sharī'ah law. Instead, the request was made to the government to take the responsibility and active

$27 \quad$ Feedbacks from seminars and legal literacy programs organized by the Sharī'ah Legal Clinic, Ahmad Ibrahim Kulliyyah of Laws, IIUM where the clients normally complain that they did not get the maintenance though the Sharī'ah Court had granted the order.

28 See Islamic Family (Federal Territories) Act 1984, s. 80.

29 See Islamic Family (Federal Territories) Act 1984, s. 110. The child is illegitimate if it is born out of wedlock and there is no mechanism to legitimize the child by subsequent marriage neither of its parent nor through adoption. The law for non-Muslim follows the English law. The fundamental test of legitimacy is on the conception of the child during the lawful wedlock of its parents i.e. six months from the date of the marriage. For further reading, see Ahmad Ibrahim, "Blood relationship as a ground of inheritance under Islamic law,” [1979] Journal of Malaysian and Comparative law, vol. 6, pp. 163-238, at p. 163. 
participation in protecting the interests of illegitimate children as regulated under the Sharī'ah law. ${ }^{30}$

Another interesting development that has been raised in the Malaysian Sharī'ah Court is in relation to the role of children in maintaining their parents. Shari`‘ ah law gives an equal emphasis on both relationships. However, it has not been extensively regulated to allow the parents to obtain a court order against their son. Until recently, the mode has swung when the Sharī'ah court takes judicial recognition of such practice. In Negeri Sembilan's case of Khalil b Ahmad $v$ Kamal b Khali ${ }^{31}$ the plaintiff (father) claimed maintenance from the defendant (son) a sum of RM36,000 on the basis of RM500 per month alleging that the defendant did not provide financial assistance for about 10 years, which was denied by the defendant. The plaintiff further claimed another RM2000 for medical expenses of the plaintiff's wife, i.e. the defendant stepmother, who was also responsible for his upbringing. The father married the stepmother after his divorce from the defendant's mother. The facts of the case revealed that both parties originally were on good terms. The relationship turned sour over a dispute regarding a piece of land and the plaintiff refused to accept monetary contribution from the defendant until the case was brought to the court.

The court ruled that the defendant had to pay maintenance on the basis of the Sharī'ah ruling that maintenance of parent is obligatory upon children (son) or grandchildren if they are financially capable. In relation to the claim, the court ruled that the Defendant had to pay RM200 per month starting from 1998 and to pay RM2000 for medical expenses of the defendant's stepmother. The basis for the claim is based on the general understanding of the Sharī'ah principle urging for respect and dutifulness to parents. ${ }^{32}$ The above decision is rarely seen in the Malaysian Syariah Court in the absence of a specific legislation addressing the issue.

$30 \quad$ This view was raised in many seminars and conferences on the basis that it is unfair to impose the liability on women alone. For example, this proposal was suggested in the Seminar on the Introduction to the Hague Conventions, 22-23 August 2005, Sabah, Malaysia where the issue on maintenance of illegitimate children was specifically addressed.

$31 \quad$ (2003) 16(1) JH 19.

32 For example, see the Qur'ān, 17:23. 
However, the creativity of the judge in finding the basis under the Shari`'ah ruling has created an avenue for elder people to get financial support.

In another development, the government is considering measures to punish those who abandon their parents. In a study done by the Ministry of Women, Family and Community, most children send their parents to care centres as they need professional help. In relation to that, some members of Parliament even requested for the deduction of salary of those who abandon their parents. However, the Minister admitted that the time has not come for the government to punish them as Malaysian generally still love their parents unless when the situation becomes serious. ${ }^{33}$

The above discussion shows that the commitment towards family members largely depends on the family culture and natural bonds that are already in place. There is no guarantee that such practice is susceptible to social change in the absence of specific legislation to address the issue. Therefore, in tackling some of the issues, other modes of financial disposition for the benefit of close family members have been initiated either through individual practices or by established financial institutions.

\section{WAȘIYYAH WĀJIBAH (COMPULSORY BEQUEST)}

Besides monetary contribution in terms of financial support, family members may also contribute through other means such as disposing of movable and immovable property by way of gift (hibah), will (wașiyyah), bequest (sadaqah) or charitable trust (waqf). All these forms of transfer are done voluntarily except in certain cases where it requires state intervention. Compulsory bequest ${ }^{34}$ is a form of state intervention where the property of a grandfather will be transferred to grandchildren after his death if there is no will made for the benefit of the grandchildren. This happens when the father or mother of the children have died earlier than their parents. The idea is to ensure that the grandchildren will have financial means to support them in the absence of both father and paternal grandfather as the main financial provider.

\footnotetext{
$33 \quad$ Elizabeth Looi, Shahrizat: “Abandoned Parents Not Yet Serious Issue,” The Star Online, April 13, 2007.

$34 \quad$ The principle is derived from general ruling on will.
} 
The general rule of inheritance does not include allotment of shares to grandchildren as they are excluded by their father and his siblings. Thus, the provision on compulsory bequest ensures that a certain portion of property is allotted to them.

There is no specific ruling addressed by the Sharī'ah primary sources. The rule is developed by the Muslim jurists on the basis of public interest (mașlahah) of grandchildren who may fall into difficulty if the other family members who are liable to support them neglect their duty. Furthermore, the injunction to make a will or bequest is strongly encouraged in Sharī'ah law. The Qur'ān states:

"It is prescribed for you when death approaches any of you, if he leaves wealth that he makes bequest to parents and next of kin according to reasonable manner.”35

Though the transfer by will is viewed as a voluntary act and a good deed, there is an opinion of the Muslim jurists who even claim that making of a will is an obligation that falls on other family members to manage the property after his death including the making of a will for the loved one i.e grandchildren. ${ }^{36}$

Since the ruling is based on juristic exercise, the practice of compulsory bequest differs from one Muslim country to another, in terms of proportion of the entitlement and gender of the grandchildren. Some allow the property to be distributed to both male and female according to the proportion in inheritance while others provide for male only as financial contributor provided that they do not receive any property by other means such as hibah, waqf, wasiyyah etc. As to proportion, some view that it takes the proportion of the parents while others allow only $1 / 3$ as generally adopted in disposing of property by will. ${ }^{37}$

In Malaysia, only the state of Selangor is receptive to the idea of wasiyyah wäjibah and makes it statutorily enforceable under the Muslim

\footnotetext{
35 The Qur'ān, 2:180.

$36 \quad$ See Sabaruddin Selamat, "Kedudukan Wasiat Wajibah dalam Islam dan Perlaksanaannya dalam Enakmen Wasiat Orang Islam (Selangor) 1999 (The Status of Compulsory Bequest and Its Implementation in the Muslim Will Enactment (Selangor) 1999),” [2006] 20(1) Jurnal Hukum, p. 21-41at p. 28.

$37 \quad$ Ibid., p. 22.
} 
Wills (Selangor) Enactment 1999. ${ }^{38}$ The law provides that if someone dies without making any will to the grandchildren of his/her son; the grandchildren are entitled to $1 / 3$ of the deceased property. This is applicable if they do not receive their portion from the deceased before his/her death. An acceptable practice is that the grandchildren must receive a portion equal to the father's portion. ${ }^{39}$ There was even a proposal to extend the practice to adopted children if there is no will. ${ }^{40}$

\section{DISPOSAL OF PROPERTY BY WAY OF GIFT (HIBAH) AND TRUST}

Another popular mode of transferring property for the benefit of family members is by way of creating an instrument, which is known as a gift or commonly known as hibah among the Muslim community in Malaysia. Though generally the property can be distributed to any family member including the heirs, most cases indicate that the gift is made for the benefit of non legal heirs such as grandchildren and adopted children. However, the transfer of the property must take place during the lifetime of the donor. In an old case of Kiah $v$ Som, ${ }^{41}$ a Malay grandmother orally gave her wooden house to her grandchild. The transaction was witnessed by two witnesses. After her death, the daughter took possession of the land, including the house that was built on it. She refused to allow the granddaughter to possess the house. The case went to the court where the court decided that the creation of hibah was valid upon the granddaughter taking possession immediately after the death of the grandmother. This type of dispute occasionally occurs in the court when the property failed to be transferred during the lifetime of the donor or it has been transferred in a suspicious manner. For example, in Zaleha Ariffin $v$ Salmah Md $\mathrm{Zain}^{42}$ the grandmother had transferred a

\footnotetext{
$38 \quad$ As gazzetted on July 1, 2004.

$39 \quad$ Muslim Wills (Selangor) Enactment 1999, section 27 (1) (2) (3).

$40 \quad$ See Ahmad Ibrahim, "Blood Relationship as a Ground of Inheritance Under Islamic Law,” [1979] Journal of Malaysian and Comparative law, vol. 6, pp. 163-238, at p. 238.

$41 \quad$ [1953] MLJ 82.

$42 \quad$ [2001] 6 CLJ 353.
} 
substantial piece of land to the granddaughter (defendant) who took care of her when she was sick. One week later, the grandmother passed away. The plaintiff, who is the auntie, challenged the validity of hibah. However, the Court decided in favour of the defendant as conditions for a valid hibah had been established.

Besides hibah, a Muslim family may also create a trust for the benefit of certain family members, usually minor children or grandchildren, where the property could not be transferred and registered in their names. ${ }^{43}$ Though in extended family, the liability will fall on paternal relations, transferring the property upon trust will further protect the interest of minor children. In Wan Naimah $v$ Wan Mohammad Nawawi ${ }^{44}$ such trust was created on an undivided share of a piece of land for the benefit of a son who was 16 years of age. The property was registered in the sister's name. The plaintiff claimed half share of the property though it was denied by the defendant (sister). Since there was sufficient proof as to the creation of a trust, the court decided in favour of the plaintiff.

Since both hibah and trust can be created without restriction as to the amount and category of recipient, the above instruments guarantee the right of minor children or other family members ${ }^{45}$ who are in need of financial assistance. However, to date, there is no statutory provision, which specifically addresses procedural requirements for the application of hibah and trust. Judges have to rely on general principles of Sharī ah law when the dispute arises.

Parents who have no son may find this as a useful instrument to transfer the whole property to the daughter(s) instead of transferring a portion to his own brother according to inheritance rule who perhaps will

\footnotetext{
43 The age of majority is 18 years age according to the Age of Majority Act 1974.

$44 \quad$ [1974] 1 MLJ 41.

$45 \quad$ Islamic Family Law (Federal Territories) Act 1984, s. 78. See also Ahmad Ibrahim, "Blood Relationship as a Ground of Inheritance Under Islamic Law," [1979] Journal of Malaysian and Comparative Law, vol. 6, pp. 163-238, 238. See also Salmiah v Zakaria (2000) 14 JH 79 where the uncle transferred a piece of land to the niece but her husband transferred it to his name. The court ordered the land to be transferred to her name.
} 
only appear after his death to claim his share of property. ${ }^{46}$ Though this portion is to be used for the benefit of the deceased daughters, there will be no guarantee that the duty will be discharged when the family tie is loose except with the court order. In relation to that, the banking industry has introduced various products in helping the property owner to further protect the interest of their loved ones by appointing the bank as a trustee. 'Gift trust' for example, is an inter vivos transfer for the benefit of successive family members as well as for the public in the form of asset protection, charity, health and education. The transaction will take place between the Donor and the Trustee on behalf of the beneficiary who does not need to be informed about the transaction. ${ }^{47}$ Even though the basis for charitable trust is for the benefit of the public, there is no doubt that such an instrument will give security in terms of financial needs in the future for the benefit of family members.

\section{CONCLUSION}

The above discussion shows that despite modernization the role of extended families is significantly relevant in releasing the burden of the other family members. The law for non-Muslims does not address the role of extended family in providing financial support except on the basis of good practices even though they are entitled to a share in the estate of the deceased if he dies intestate. The Muslims on the other hand, have a comprehensive regulation under the Sharī'ah law regulating the role of extended family. However, the majority of them are not available in statutory form that could be enforced in the court of law and to alert members in the family that they have a role to play towards the others in terms of monetary contribution. In order to support the practice, there is a need to have rules and regulation or even policies addressing

46 This is because the daughter will get only half of her share or in case two or more daughters; they share $2 / 3$ of the property. The balance will be transferred to the paternal uncle to assist him in taking care of the nieces according to the inheritance law.

$47 \quad$ One example of the products introduced by the Islamic Bank of Malaysia Trust Limited. See www.bankislam.com as retrieved on the $18^{\text {th }}$ of May 2007. 
their roles and responsibilities that could be the basis for the claim in case of neglect. The creation of certain instruments for disbursement of property after the death of the main financial provider by financial institutions may provide some relief in safeguarding future needs for financial assistance. 